\title{
GEOTECHNICAL STRUCTURES: INVESTIGATION OF DRILLED SHAFTS IN HIGHLY EXPANSIVE SOILS
}

\author{
Mohammed FARUQI, Eliborio PENA, Jina BALOGH \\ Department of Civil and Architectural Engineering, MSC 194, \\ Texas A and M University - Kingsville, TX 78363, USA
}

Received 17 November 2013; accepted 01 October 2014

\begin{abstract}
Construction over extremely expansive soils raises the risk of structural foundation failure and potential failure to the building itself. This is due to shrinkage and swell characteristics of expansive soils. This works presents an extensive case study of a distressed building built on drilled piers and expansive soil, and describes innovative practical ideas that can be used in the renovation of its foundation. The building is located west of San Antonio, Texas, USA. This building has experienced significant settlements and differential building movement resulting in widespread building distress. The following foundation based structural distresses were found in the building: 1) vertical movements of more than $300 \mathrm{~mm}$, 2) bearing surface had completely spalled away and the beams were supported solely by bent and corroded anchor bolts which were not well confined in the surrounding concrete, 3 ) the beam rotations and lateral movement caused the steel stub columns supporting the floor framing to tilt sideways. This created eccentric support conditions that could result in sudden instability failure of either the beams or columns, and 4) under bathrooms in the northwest corner of the building, significant corrosion of steel framing was observed due to long term exposure to moisture leaking through cracks in the floor slab above. Drilled piers were studied using spot study, soil data obtained from boreholes and laboratory tests based on American standards. It is recommended that $0.5 \mathrm{~m}$ diameter piers of lengths $18.3 \mathrm{~m}$ with positive skin friction to prevent uplift, and a load carrying capacity of $1737 \mathrm{kN}$ be used to rehabilitate the failing foundation. Also, new shafts are to be designed for a minimum factor of safety 2.5 and the rejection of an unacceptable pier required installation of one or more replacement piers at locations that would facilitate load transfer from the structure above.
\end{abstract}

Keywords: construction, foundation, building, drilled piers.

\section{Introduction}

Construction over extremely expansive soils raises the risk of structural foundation failure and potential failure to the building itself (Service Load Design Method: Allowable Stress Design (AASHTO Division 1 Design: 2002)). Moisture changes can cause the soil to heave and contract. The potential for cracking in pier caps, structural columns and post tensioned beams is greatly increased. Historically, vertical movement of up to $325 \mathrm{~mm}$ have been recorded within the portion of an adjacent building. The structure is founded on piers, and at least two area of the building have become essentially unusable due to movement resulting of heave and settlements. These failures have been attributed to several factors. The most important ones are: inadequate dead load and insufficient embedment into un-weathered strata of drilled piers. Based on observations, there seems a direct correlation between the amount of heave experienced by the piers and columns in the adjacent structure and the dead load on them. The highest loaded one experiencing the least heave. Additional factors include: inadequate internal rein- 
forcement to counteract tensile forces from adhesion against the pier shafts, introduction of moisture into the bearing horizon by construction activities, and changes to drainage around the building perimeter (T258-81: 2004). Even if the design is sound, the last two factors, can induce a failure, since moisture change is the catalyst for others. Improper design in expansive soils, can cause costly repairs, delays, and inconvenience to contractor and/or user.

\section{Summary of challenges}

Significant building movement and distress have been observed in the Community Activity Centre (CAC), Building 6576.

Evidence of significant building movements includes sloping floors and widespread cracking in interior and exterior walls (see Figs 1-3). An interior spot elevation study was performed to assess the location and severity of vertical building movements. Differences in finish floor elevations across the building footprint were found to be more than $305 \mathrm{~mm}$.

Building 6576 imposes imminent public danger due to distress under the first floor. The following structural distress was observed under the level 1 suspended floor slab via spot study:

- Around the building perimeter, steel girders supporting floor joists have begun to pull away from the concrete pilasters they bear on (see Figs 4-6). As a result, shear stresses applied thru the anchor bolts have caused the outside face of the pilasters to spall away. In many cases the bearing surface has completely spalled away and the beams are supported solely by bent and corroded anchor bolts which are not well confined in the surrounding concrete. Partial floor collapse due to this condition could occur any time and is more likely under the presence of live load.

- Building settlements on the north side of the assembly room near the stage have caused underlying steel beams to bend, rotate and shift laterally. The beam rotations and lateral movement has caused the steel stub columns supporting the floor framing to tilt sideways. This creates eccentric support conditions that could result in sudden instability failure of either the beams or columns (see Figs 7-8)

- Under bathrooms in the northwest corner of the building, significant corrsion of steel framing was observed due to long term exposure to moisture leaking through cracks in the floor slab above. The load carrying capacity of the corroded framing members may be significantly reduced (see Figs 9-10).

\section{Geotechnical and other investigation}

A geotechnical investigation was performed to assess the cause of building movements. Borings around the building indicate the presence of highly expansive clay soil, The geotechnical report states that the existing foundations are not deep enough to resist soil uplift forces and are unable to prevent building movement due to expansive soils. The geotechnical investigation also revealed high moisture contents in the expansive clays down to an elevation of nearly $9.1 \mathrm{~m}$ below grade due to a water-bearing gravel layer. Most soil strata with expansive clay soils near the surface have a moisture-affected zone of 3-4.6 m. Existing drilled pier foundations were founded in the gravel which is approximately 1.5-3.0 m below grade.

Poor moisture control under and around building perimeter also contributed to building movement (Various... 2004). Poor grading and drainage around the building have resulted in saturated ground conditions at the perimeter of the building. Downspouts from the roof do not adequately directly storm water away from the building. During dry periods the previously saturated soils have shrunk and settled creating low points for future moisture to collect. Extreme wetting and drying in soils adjacent to pier supports have resulted in significant movements that have been observed. New pier foundations would be needed in Building 6576 in order to stabilize the building and prevent further differential movements. Most of the interior finishes, partitions, mechanical, electrical, and plumbing systems on the first floor would also need to be repaired or replaced as a result of stabilizing/drilling operations.

The estimated cost of structural repairs is approximately $\$ 5,900,000$. The rough order of magnitude includes the following:

- Roof replacement per the scope of work.

- New pier foundations.

- Building levelling operations.

- Removal and replacement of architectural, mechanical, electrical, and plumbing components to accommodate foundation installation.

- Replacement of site concrete; and

- Repairs under the $1^{\text {st }}$ floor suspended slab. 


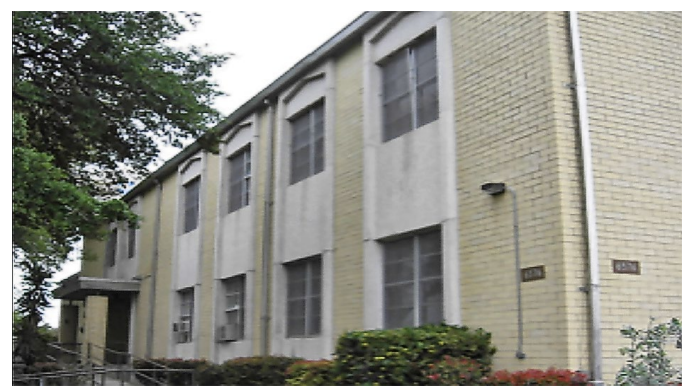

Fig. 1. Entrance of CAC building

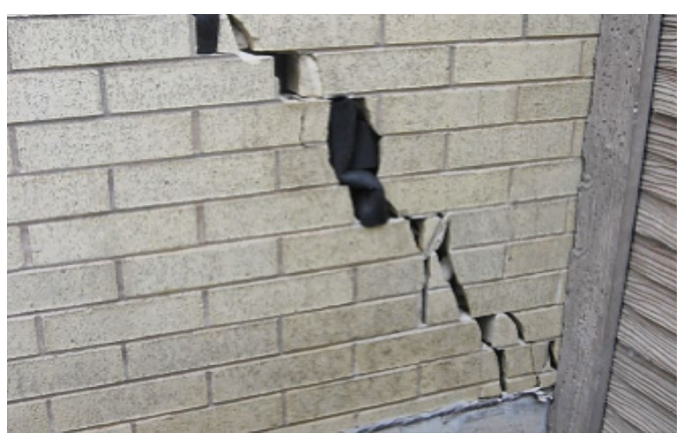

Fig. 2. CAC broken wall

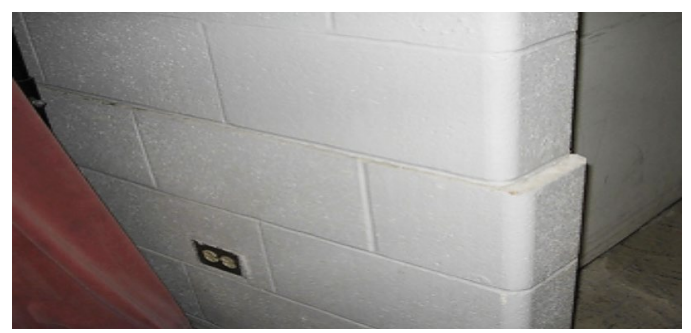

Fig. 3. CAC shifted wall

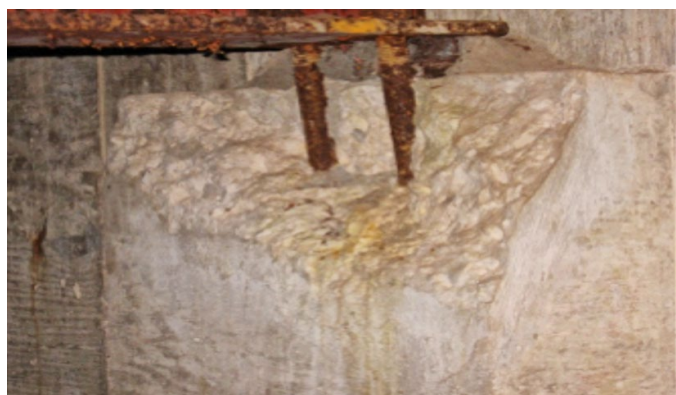

Fig. 4. Expose rebar in CAC foundation

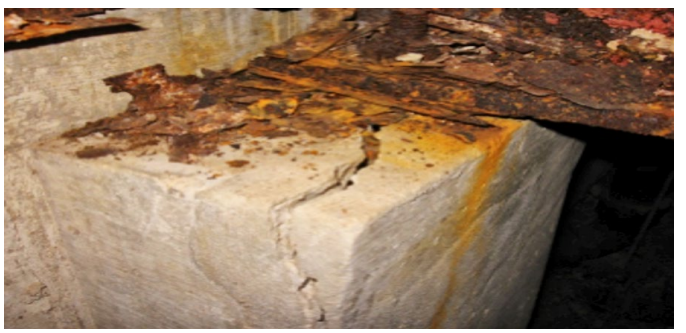

Fig. 5. Damage CAC foundation

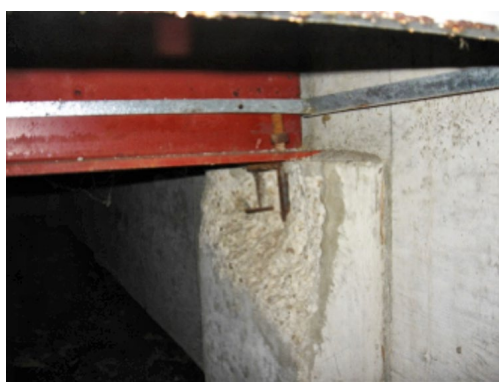

Fig. 6. CAC foundation

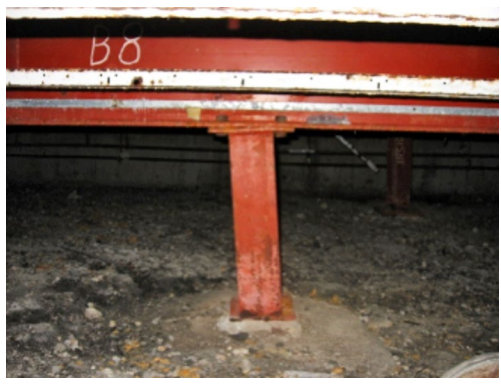

Fig. 7. Bent/shifted CAC foundation

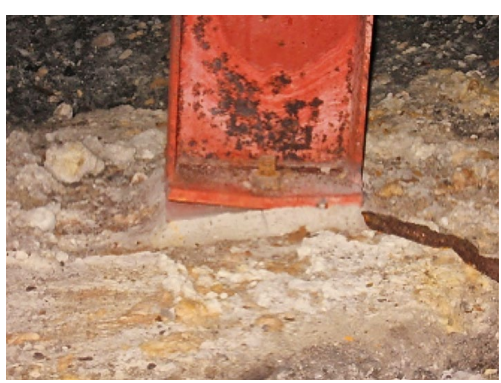

Fig. 8. Bent I-beam supporting column

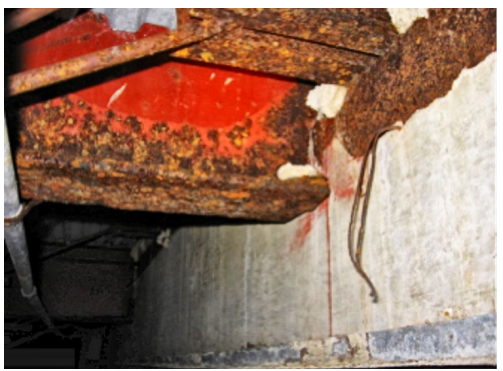

Fig. 9. Damaged beams

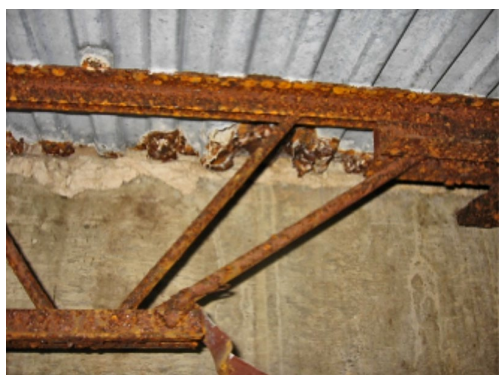

Fig. 10. Damaged support 


\section{Overall view and scope of research}

Building 6576 is located west of San Antonio, Texas, USA. This building has experienced significant settlements and differential buildi- ng movement resulting in widespread building distress. In addition, severe damage to steel framing and connections under the first floor slab has created extremely dangerous floor support conditions. These unsafe conditions represent a significant risk to life safety and imminent public danger.

Although lots of repairs are needed in this building; however, this work will only focus on improving the foundation. Therefore, this works presents an extensive case study of a distressed building built on drilled piers and expansive soil, and describes innovative practical ideas that can be used in the renovation of its foundation.

\section{Field investigation}

In this study, the subsurface exploration program consisted of two borings around the building. The first boring was drilled to a depth of $18.3 \mathrm{~m}$ and the second boring to a depth of $21.3 \mathrm{~m}$. Fat clay with sand, sandy clay, clayey gravel, and fat clay were respectively observed within the following ranges for the first boring: 0-0.6 m, 0.6-4.6 m, 4.6-5.2 m, 5.2-6.1 m, and 0.6$18.3 \mathrm{~m}$. On the other hand, for the second boring, fat clay with sand, clayey gravel, sandy lean clay, and fat clay were respectively observed within the following ranges: $0-2.4 \mathrm{~m}, 2.4-3 \mathrm{~m}, 3-4.3 \mathrm{~m}$, and $4.3-21.3 \mathrm{~m}$. The borings were drilled using the procedures described in reference to the American Society of Testing Materials report with the following exception: samples were obtained at about $0.6 \mathrm{~m}$ intervals until tan and grey fat clay was encountered (approximately 3.7 to $6.1 \mathrm{~m}$ depth and at $1.5 \mathrm{~m}$ intervals thereafter) (Design... 1998). Most of the samples types were thin-walled type with a few standard.

\section{Laboratory testing}

The laboratory testing program included identification and classification testing of the strata encountered in the subsurface. Soil classification tests, including Atterberg limit determinations (ASTM D4318) and partial grain-size analyses (ASTM D422), were cond-ucted on representative samples of the soil strata (D4318: 2007) and (D422-63: 2007). Unconsolidated undrained triaxial compress-ion test (ASTM D2859), were conduc- ted on selected samples (D2859-06: 2011). The classification and compressive test included unit dry weight determinations (D7263: 2008).

\section{Subsurface conditions}

The classification and plasticity of soils (D2487: 2007) at the site consisted of highly plastic "fat" clays $(\mathrm{CH})$ with intermediate layer of low plasticity "lean" clay $(\mathrm{CL})$, containing varying amounts of sand and gravel. Portions of the near-surface fat clays may be comprised of fill material. The lean clays were encountered at depths of 0.6 to $1.8 \mathrm{~m}$, extending to depths ranging from about 3.7 to $6.1 \mathrm{~m}$ (T258-81: 2004).

The near-subsurface fat clays had measured liquid limits ranging from 60 to 66 and plasticity indices (PIs) of 40 to 46 . The lean clays and gravelly zone had liquid limits ranging from 22 to 41, PIs ranging from 6 to 25 , and percentages passing the No. 200 sieve (fines) ranging from 26 to 74 percent. The deeper fat clays had measured liquid limits ranging from 83 to 100 and PIs from 59 to 76 .

The boring indicate that the fat clays encountered near the surface and below about 3.7 to $6.1 \mathrm{~m}$, had moisture content values typically ranging from about 25 to 30 percent. The intermediate lean clays had moisture content values ranging from 23 to 36 percent.

The liquidity index (LI) is defined as the difference between the moisture content and the plastic limit, divided by the plasticity index (Das 2006). The liquidity index provides a measure of the moisture content relative to the Atterberg limits of the sample. For the same type of soil, the higher the moisture content, the higher the liquidity index. For example, LI of zero indicates that the moisture content is equal to the plastic limit; and LI of +0.50 indicates the moisture content is halfway between the plastic limit and liquid limit. A negative LI indicates that the moisture content is less than the plastic limit.

The liquidity index was computed for the tested underlying clay samples The computed LI values of the tested samples generally followed a trend similar to the measured moisture contents. However, the LI's of the lean clays displayed wide variation. Such wide variation is common in the presence of low plasticity and/or variable plasticity materials. The LI values of the tested fat clay samples typically ranged from +0.05 to +0.14 near the surface and decreased to near zero below $8.2 \mathrm{~m}$. 


\section{Design of drilled piers in expansive soil}

Shafts in expansive soil were designed by total and effective stress methods of analysis (Lymon et al. 2006), for undrained and draine- ed loading conditions. The potential for external loading on the shaft by vertical ground movements was also considered as part of the design. This is because vertical ground movement results in negative skin/side friction due to settlement of compressible soils or may result in uplift loads due to heave of expansive soils (Design Part B Service Load Design Method Allowable Stress Design, AASHTO Division 1). For design purposes, the full magnitude of maximum vertical ground movement was assumed, in Lackland AFB and the areas of Building 6576 a professional judgment of $304.8 \mathrm{~mm}$ was used.

The estimated undrained shear strength values of the cohesive samples are included on the boring logs. The estimated shear strength values generally increase with depth (Davis, Booker 1973). Hand penetrometer values averaged about $95.8 \mathrm{kPa}$ near the surface and increasing to over $215.5 \mathrm{kPa}$ (the maximum value indicated by the penetrometer) below $5.6 \mathrm{~m}$ depth. Unconsolidated undrained (UU) triaxial compressive strength test (D2850: 2007) also generally increased with depth and ranged from 119.7 to $220.2 \mathrm{kPa}$ near the surface and increased to 435.7 to $560.2 \mathrm{kPa}$ at depths of 16.8 to $18.3 \mathrm{~m}$. These values suggest the near surface samples were stiff to very stiff in consistency and the deeper samples were very stiff to hard in consistency.

\section{Skin friction}

The potential for external loading on a shaft by negative skin friction/down drag due to settlement of compressible soil was also considered as part of the design. Evaluation of negative skin friction included a loadtransfer method of analysis to determine the neutral point (point of zero relative displacement) and load distribution along shaft. Due to the possible time dependence associated with vertical ground movement, the analysis considers the time period relating to the maximum axial load transfer to the shaft. Further, negative skin friction loads, that may cause, excessive settlement were reduced by roughing the edges of the shaft. Representative allowable skin friction and end bearing values for specific depths are presented in Table 1 . It should be noted that the capacity is calculated from the upper $1.8 \mathrm{~m}$ below the existing or final ground surface, whichever is lower.
Table 1. Skin friction and end bearing values for specific depths

\begin{tabular}{|c|c|c|}
\hline Depth $(\mathrm{m})$ & $\begin{array}{c}\text { Allowable skin } \\
\text { friction } f_{s}(\mathrm{kPa})\end{array}$ & $\begin{array}{c}\text { Allowable end } \\
\text { bearing } q_{b}(\mathrm{kPa})\end{array}$ \\
\hline 0 to 1.8 & Neglect & Neglect \\
\hline 1.8 to 4.6 & 33.5 & ----- \\
\hline 4.6 to 9.1 & 39.5 & ----- \\
\hline 9.1 to 18.3 & 79.0 & 861.8 \\
\hline
\end{tabular}

The allowable shaft capacity may be computed using the following equation:

$$
Q_{t c}=Q_{s}+Q_{b}=\Sigma f_{s}^{*} d A+q_{b}^{*} A,
$$

$Q_{t c}=$ total allowable compressive capacity; $Q_{s}=$ allowable capacity due to side friction; $Q_{b}=$ allowable capacity due to end bearing; $f_{s}=$ allowable load transfer due to side resistance at depth $z ; d A=$ differential area of the perimeter along sides of drilled shaft over the penetration depth; $q_{b}=$ allowable unit end bearing capacity; and $A=$ bottom area of pier.

For example, the capacity of a $0.5 \mathrm{~m}$ diameter pier bearing at $18.3 \mathrm{~m}$ in depth is calculated as shown below:

$$
\begin{aligned}
& Q_{t c}=f_{s 1}{ }^{\star} d A+f_{s 2}{ }^{\star} d A+f_{s 3}{ }^{\star} d A+q_{b}{ }^{\star} A, \\
& Q_{t c}=\left[33.5^{\star} \pi^{\star} 0.5^{\star}(4.6-1.8)+\right. \\
& 39.5^{\star} \pi^{\star} 0.5^{\star}(9.1-4.6)+79.0^{\star} \pi^{\star} 0.5^{\star} \\
& \left.(18.3-9.1)+861.8^{\star}(0.5)^{2}(\pi / 4)\right]=1737 \mathrm{kN} .
\end{aligned}
$$

\section{Groundwater conditions around 6576}

The borings were carried out using a dry technique; neither water nor other drilling fluid was introduced. Free water was observed at a depth of $18.3 \mathrm{~m}$ at the first boring location during drilling and at a depth of $15.4 \mathrm{~m}$ upon completion of drilling. Readings were again taken twenty-four hours after the boring completion and free water was observed at a depth of $2.3 \mathrm{~m}$. No free groundwater was observed at the second boring location. A reading of the groundwater monitoring well was taken in a previous test. The groundwater was observed at a depth of $11.9 \mathrm{~m}$. It should be noted that groundwater levels might fluctuate seasonally in response to precipitation, landscape irrigation, and changes in drainage surface patterns.

When piers are placed on expansive soil, the load on the bearing material must be sufficient to resist uplift as determined by appropriate tests, or the pier bearing level must be situated at sufficient depth to preclude the moisture content that may vary after construction (Design... 1998). 


\section{Active zone}

Typically the active zone in the San Antonio area is on the order of $4.6 \mathrm{~m}$ in depth. However, the active zone in the vicinity of the project site may extend to depths greater than $4.6 \mathrm{~m}$. Based on moisture, liquidity index data presented on boring logs, and previous experience, the active zone is, more likely than not, on the order of $8.2 \mathrm{~m}$ in depth. A minimum of $215.9 \mathrm{~mm}$ of potential vertical movement can be anticipated for the site soils. This is based on estimated heave and previous experience.

Moisture variation in the expansive soil at the site were also responsible for the vertical movement of the subsoil (Field 1965; Bozozuk 1962). This potential vertical movement was able to mobilize uplift forces along the drilled shafts within the active zone. As indicated earlier, our interpretation of the moisture and liquidity index values indicate an active zone depth of approximately $8.2 \mathrm{~m}$. The uplift capacity may be computed using the following equation:

$$
Q_{\mathrm{u}}=\Sigma f_{\mathrm{s}}{ }^{*} d A \text {. }
$$

Negative skin friction values for specific depths through the interpreted active zone are presented in Table 2.

Table 2. Skin friction values and depth

\begin{tabular}{|c|c|}
\hline Depth $(\mathrm{m})$ & Negative-Skin Friction6 $f_{s}(\mathrm{kPa})$ \\
\hline 0 to 1.8 & -39.5 \\
\hline 1.8 to 3.7 & -52.7 \\
\hline 3.7 to 8.2 & -79.0 \\
\hline
\end{tabular}

Using the previous example, negative skin friction can be calculated as shown below:

$$
\begin{aligned}
& Q_{u}=-f_{\mathrm{s} 1}{ }^{*} d A-f_{s 2}{ }^{*} d A-F_{\mathrm{s} 3}{ }^{*} d A, \\
& Q_{u}=[-39.5(1.8-0)-52.7(3.7-1.8)- \\
& 79.0(8.2-3.7)](\pi)(0.5)=-827 \mathrm{kN} .
\end{aligned}
$$

But remember the rest of the length of the shaft with positive skin friction:

$Q_{u}=f_{\mathrm{s} 4}{ }^{\star} d A+f_{s 5}{ }^{*} d A=$

$[39.5(9.1-8.2)+79.0(18.3-9.1)](\pi)(0.5)=1198 \mathrm{kN}$;

therefore

$Q_{u}=1198 \mathrm{kN}-827=371 \mathrm{kN}$.

A positive skin friction governs at a depth of 18.3 $\mathrm{m}$ preventing an uplift force in a given pier. However, if the depth of the pier was less than this, for example, the outcome would be different.
Positive skin friction for a depth of $15.2 \mathrm{~m}$ :

$Q_{u}=f_{\mathrm{s} 4}{ }^{*} d A+f_{s 5}{ }^{*} d A=[39.5(9.1-8.2)+$

$79.0(15.2-9.1)](\pi)(0.5)=813 k N$;

therefore

$Q_{u}=813 k N-827=-14 \mathrm{kN}$.

An uplift of approximately $14 \mathrm{kN}$ can occur. This can cause potential damage to the above structure. Shorter drill piers than required in Building 6576 had a big role in foundation failure and could have been avoided if drilled to a safe depth.

\section{Factor of safety in drilled piers}

New shafts at Building 6576 were designed for a minimum factor of safety 2.5. This minimum factor of safety is based on an assumed normal level of field quality control during shaft construction, the subsurface cond- itions, structural loads, and degree of confidence in the subsurface parameters.

\section{Inspection}

Pier drilling inspections were carried out by a geotechnical engineer. This is important to correct defective piers. The defective piers were corrected at an early stage using the following practical options: 1) investigation of the installed pier, 2) immediate re-installation before the concrete set up, and 3) rejection of an unacceptable pier required installation of one or more replacement piers at locations that would facilitate load transfer from the structure above.

Figures 11 and 12 show defective piers. A poor quality control was kept which lead to 119 of the 125 piers to be defective.

\section{Conclusions, alternative methods in progress, and challenges}

Building 6576 has experienced significant settlements and differential building movement resulting in widespread building distress. Although lots of repairs are needed in this building; however, this work only focused on improving its foundation. Drilled piers were studied using spot study, soil data obtained from boreholes and laboratory tests based on American standards. It is recommen-ded that $0.5 \mathrm{~m}$ diameter piers of lengths $18.3 \mathrm{~m}$ with positive skin friction to prevent uplift, and a load carrying capacity of $1737 \mathrm{kN}$ be used to rehabilitate the failing foundation. Also, new shafts are to be designed for a minimum factor of safety 2.5 and the 


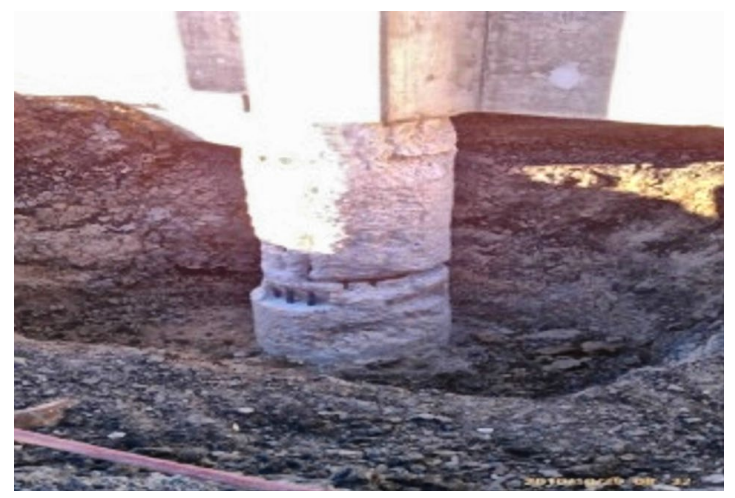

Fig. 11. Exposed rebar in pier

rejection of an unacceptable pier requires installation of one or more replacement piers at locations that would facilitate load transfer from the structure above.

Contractors of the building are carrying out research with alternative method, for example, pre-drilling and double bells.

Pre-drilling is being used instead of steel casing when groundwater is encountered. The shafts are over drilled by $152.4 \mathrm{~mm}$. For example, if the design diameter is $609.6 \mathrm{~mm}$. The shaft is drilled to $762 \mathrm{~mm}$. Once water is encountered, the shaft receives flowable fill, a soft mix of concrete approximately $2068.4 \mathrm{kPa}$ strength mix. In three days the contractor re-drills the shaft, in most case, the water has been sealed.

This method, however, has brought some concerns dealing with the stability of native soils surrounding the flowable fill. In the active zone when there is a potential for shrink and swell, how is the flowable fill going to react? Is there going to be a void space between flowable fill and soil causing water to seep into un-weathered shale? These are just some of the geotechnical questions that have arisen from these attempts.

Double bell is being used in a different construction project at the base. It has been recommended that the engineers utilize the proper belling tool and method to achieve bell geometry per design. If the proper geometry is not obtained, there could be increased risk that constructed bells would be structurally deficient. This method could adversely affect structural integrity and quality since we will not truly know what these bells would look like $21.3 \mathrm{~m}$ below grade. There are also concerns about the stability of the bell excavation with respect to the ability of the driller to effectively clean out the loose cuttings from the auger and the bell.

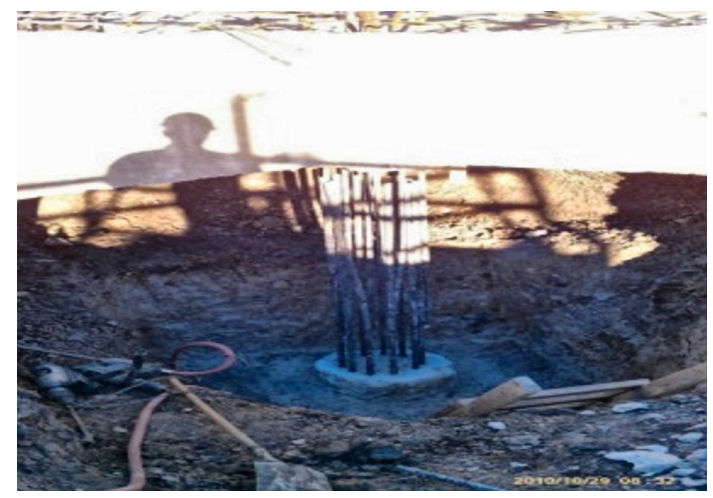

Fig. 12. Grade beam over exposed pier

This work still remains open for future improvements. It is unknown how these new construction deviation or alteration to pier design will affect the structural stability of building over highly expansive soils.

\section{References}

AASHTO Division 1 Design: 2002. Service load design method: Allowable stress design. American Association of State and Highway Transportation Officials.

Bozozuk, M. 1962. Soil shrinkage damages shallow foundation at Ottawa, Engineering Journal 45(7): 33-37.

D2487: 2007. Standard practice for classification of soils for engineering purposes. American Society for Testing Materials, ASTM. Developed by Subcommittee: D18.07 [Geotechnical Engineering Standard].

D2850: 2007. Standard test method for unconsolidated-undrained triaxial compression test on soils. American Society for Testing Materials, ASTM. Developed by Subcommittee: D18.05 [Geotechnical Engineering Standard].

D2859-06: 2011. Standard Test Method for Ignition Characteristics of Finished Textile Floor Covering Materials. American Society for Testing and Materials, ASTM. Developed by Subcommitee: E05.22 [Geotechnical Engineering Standard].

D422-63: 2007. Standard Test Method for Particle-Size of Soils. American Society for Testing and Materials, ASTM. Developed by Subcommittee: D18.03 [Geotechnical Engineering Standard].

D4318: 2007. Standard test methods liquid limit, plastic limit, and plasticity index of soils. American Society for Testing Materials, ASTM. Developed by Subcommittee: D18.03 [Geotechnical Engineering Standard].

D7263: 2008. Standard test methods for laboratory determination of density (unit weight) of soil specimens. American Society for Testing Materials, ASTM. Developed by Subcommittee: D18.03 [ Geotechnical Enginering Standard].

Das, B. M. 2006. Principles of geotechnical engineering. $7^{\text {th }}$ ed. Cengage Learning. 608 p.

Davis, E. H; Booker, J. B. 1973. The effect of increasing strength with depth on the bearing capacity of clays, Geotechnique 23(5): 551-563. http://dx.doi.org/10.1680/geot.1973.23.4.551

Design and construction of drilled piers 1998. American Concrete Institute, ACI 336.3R-93, Reported by ACI Committee 336. 
Field, J. 1965. Tolerance of structures to settlements, Journal of Soil Mechanics and Foundations Division 91(SM3).

Lymon, C. R; William, M. I.; Shin-Tower, W. 2006. Analysis and design of shallow and deep foundations. Wiley. 600 p. ISBN 978-0-471-43159-6.

T258-81: 2004. Standard method of test for determining expansion soils. American Association of State and Highway Transportation Officials, AASHTO.
Various Aspects of Expansive Soils Relevant to Geo-Engineering Practice. 2004. Advanced Engineering Geology \& GeoEngineering Geotechnics (GE 441).

Mohammed FARUQI. Professor in the Department of Civil and Architectural Engineering at Texas A \& M University-Kingsville. Research interests: application of composites to concrete structures, foundations, structural dynamics and earthquake engineering.

Eliborio PENA. Graduate student in the Department of Civil and Architectural Engineering at Texas A \& M University-Kingsville. Research interests: foundations and structural design.

Jina BALOGH. Undergraduate student in the Department of Civil and Architectural Engineering at Texas A \& M UniversityKingsville. Research interests: structural design. 